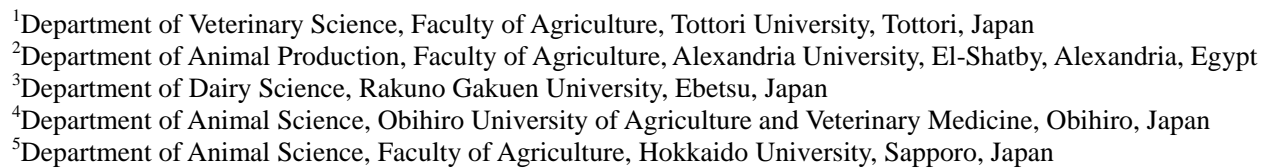

\title{
Effect of Protein Sources with Different Rumen Degradability in a Diet on the Efficiency of Utilization of Metabolizable Energy by Calves
}

\begin{abstract}
To evaluate the effect of dietary protein of diverse rumen degradability on the efficiency of metabolizable energy (ME) utilization by calves at the growth and maintenance levels of feeding. A total of 54 energy balance trials were conducted using 18 Holstein castrated male calves given four diets containing soybean meal (SBM), cottonseed meal (CSM), heated soybean meal (HSBM) and corn gluten meal (CGM) as a main source of protein. The trials were carried out at the ages of 13 weeks for the growth (G) level of feeding and 15 weeks for maintenance (M) followed by the 24-h measurement of fasting (F) heat production after 3-day fasting. The dg values were $0.657,0.543,0.463$ and 0.413 for SBM, CSM, HSBM and CGM, respectively. The regression analyses of energy retention (ER, $\mathrm{kJ} / \mathrm{W}^{0.75}$ ) on the intake of ME (IME, $\mathrm{kJ} / \mathrm{W}^{0.75}$ ) above the maintenance level revealed no significant differences among diets and gave a following pooled equation: $\mathrm{ER}=0.56( \pm 0.04) \mathrm{IME}$ $311, r=0.897(\mathrm{P}<0.01)$. The below $\mathrm{M}$ level resulted in the following two distinct equations for the diet with a higher dg of protein source and that of a lower dg: $\mathrm{ER}=0.77( \pm 0.02) \mathrm{IME}-403, \mathrm{r}=0.994(\mathrm{P}<0.01)$ for SBM+CSM. ER $=0.60( \pm 0.03)$ IME $-350, r=0.982(\mathrm{P}<0.01)$ for HSBM+CGM. We concluded that ME utilization for maintenance may be influenced by the protein sources of different dg, but not for growth.
\end{abstract}

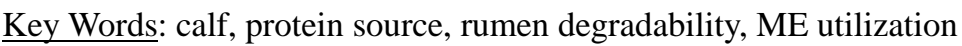

\section{Zusammenfassung}

Titel der Arbeit: Einfluss von Ernährungsprotein mit unterschiedlichem Pansenabbau auf die Effizienz der metabolischen Energienutzung bei Kälbern

Untersucht wurde der Einfluss von Futterprotein bei unterschiedlichem Pansenabbau auf die Effizienz der metabolischen Energienutzung bei Kälbern während des Wachstums und dem Nachsorgestand. Ingesamt wurden 54 Energieausgleichversuche mit 18 kastrierten Holsteinbullenkälbern durchgeführt. Als Eiweißquelle dienten Sojabohnenmehl (SBM), Baumwollsamenmehl (CSM), erhitztes Sojabohnenmehl (HSBM) und Getreideklebermehl (CGM). Die Versuche für die Wachstumsphase wurden im Alter von 13 Wochen, die für die Nachsorge mit 15 Wochen durchgeführt, an die sich die 24 h-Messung der Fastenwärmeproduktion nach einer 3-tägigen Fastenzeit anschloss. Die Werte für den effektiven Stickstoffabbau des Eiweißfutters (dg) lagen dabei bei 0,657, 0,534, 0,463 und 0,413 für SBM, CSM, HSBM bzw. CGM. Die Regressionsanalyse der Energieretention (ER, $\mathrm{kj} / \mathrm{W}^{0.75}$ ) bei der Aufnahme der metabolischen Energie (IME, $\mathrm{kJ} / \mathrm{W}^{0,75}$ ) im Nachsorgestand zeigte keine wesentlichen Differenzen zwischen den Ernährungsgruppen und ergab folgende zusammengefasste Gleichung: ER = $0.56( \pm 0.04)$ IME $-311, r=0,897(\mathrm{P}<0,01)$. Im Nachsorgestand ergaben sich die zwei Gleichungen bei der Ernährung mit höherem dg bzw. niedrigerem dg der jeweiligen Proteinquelle wie folgt: ER = 0,77 $( \pm 0.02)$ IME 403, $r=0,994(\mathrm{P}<0,01)$ für SBM+CSM bzw. ER $=0,60( \pm 0,03)$ IME $-350, r=0,982(P<0,01)$ für HSBM+CGM. Daraus ist zu schlussfolgern, dass die Nutzung der metabolischen Energie bei der Nachsorgephase durch die dg der verschiedenen Proteinquellen beeinflusst wird, während das für die Wachstumsphase nicht zutrifft.

Schlüsselwörter: Kalb, Proteinquelle Pansenabbau, Nutzung der metabolischen Energie 


\section{Introduction}

The new approach for the nitrogen $(\mathrm{N})$ requirement for the ruminant has been first introduced in the British feeding standard of ruminant livestock in 1980 (ARC, 1980). The $\mathrm{N}$ requirement consisted of rumen degradable protein (RDP) for ruminal microorganisms and undegraded dietary protein (UDP) for the direct needs of the animal tissue. Since then, the new theory has been adopted to the feeding standard in diverse countries. These $\mathrm{N}$ requirements were based on the metabolizable energy (ME) supply. The UDP supplemented to low-quality forages often increased live weight gain and the efficiency of feed conversion (VON KEYSERLINGK and MATHISON, 1993). An increased efficiency of energy utilization has been suggested to be responsible for the improvement of animal performance (GILL et al., 1987; VEIRA et al, 1985, 1988). Yet, VON KEYSERLINGK and MATHISON (1993) have shown that supplementation of UDP did not affect the efficiency of ME utilization by lambs. VEIRA et al (1990) found that supplementation with soybean meal, a protein more extensively degraded in the rumen than fish meal, produced a similar growth response to fish meal. Furthermore, studies on the energy metabolism applicable to the changes in the characteristics of protein are limited (SEKINE et al, 1988; ORITIGUES et al, 1990; SEKINE and ASAHIDA, 1990; VON KEYSERLINGK and MATHISON, 1993) and results were inconsistent. There has been no study reported on the relations between the rumen degradability of protein sources and the efficiency of utilization of $\mathrm{ME}$ for the growth and maintenance of growing calves. The present study was designed to evaluate the effect of protein sources of diverse rumen degradability in a diet on the efficiency of ME utilization by calves at the growth and maintenance levels of feeding.

\section{Materials and Methods}

Animals used were 26 Holstein-Friesian castrated male calves weaned at 6 weeks of age. They were kept in individual crates and were given either one of the diets containing 1) soybean meal (SBM), 2) cottonseed meal (CSM), 3) heated soybean meal (HSBM) and 4) corn gluten meal (CGM) as a main source of protein. SBM represented a highly degradable protein source, CSM, a medium degradable source, HSBM, a slowly degradable source and CGM, the least degradable source. HSBM was prepared by heating SBM at $130^{\circ} \mathrm{C}$ for 2 hours. Diets were formulated to be isocaloric and isonitrogenous. Each diet consisted of 6 parts of concentrate and 4 parts of first cut orchardgrass hay (Table 1) on an air dry-matter basis, and contained $24 \mathrm{~g}$ of nitrogen (150 g as crude protein) and 18.7 MJ of gross energy (GE). Calves were divided into 4 groups of either 7 or 6 and randomly allocated to either one of 4 diets. Two calves of each group were fitted with rumen cannulae to determine the ruminal degradability of protein of each protein source using in situ technique (SEKINE et al., 1992). The rest of animals (5 or 4) in each group were used for an energy balance trial carried out at 12 to 13 weeks of age for the growth level of feeding and at 14 to 15 weeks for maintenance. Then, a measurement was followed by the 24-h measurement of fasting heat production after 3-day fasting (SEKINE et al., 2003). Animals were offered diets at a level sufficient for a daily gain of $0.5 \mathrm{~kg}$ at the growth feeding level presented in Japanese Feeding Standard for Dairy Cattle (AFFRC, 1999). Limited rather than ad libitum quantities of feed offered were used for growth period so that differences in digestibility and metabolizability of energy, and the heat production of calves would be 
independent on the differences of dry-matter intake (DMI) and dependent on the treatment. Each trial had a 7-day preliminary and collection periods for growth and maintenance level with a 24-h respiratory measurement on the last day of the collection period, using a ventilated open-circuit head hood with a sufficient space for feed trough and water and equipped with breather bag to avoid escaping the inner air of hood by sudden change of posture by calves or sudden movement of their head. Samples of feed, feed refusals, feces and urine were collected daily for 7 days and pooled for each animal. The chemical composition was analyzed by the methods by AOAC (1970). Neutral detergent fiber (NDF) and acid detergent fiber (ADF) were determined using the method described by GOERING and VANSOEST (1970). Degradability of nitrogen in the rumen was calculated by the equation presented by ORSKOV and McDONALD (1979) using the results obtained by nylon bag technique. The equation used was as follows: $\mathrm{P}=\mathrm{a}+\mathrm{b}\left(1-\mathrm{e}^{-\mathrm{ct}}\right)$, where $\mathrm{a}, \mathrm{b}$ and $\mathrm{c}$ were constants fitted by an iterative least-squares procedure. The effective degradability (dg) of nitrogen for protein feeds was calculated by the following equation presented by ORSKOV and McDONALD (1979): $d g=a+b c /(c+k)$, where $k$ was the ruminal passage rate determined by the chromium mordanted NDF. Calculations were prosecuted by pooled results obtained by two animals per treatment. Statistical analyses, thus, were not possible for the values of $\mathrm{dg}$, degradation kinetics of $\mathrm{N}$ and the passage rate due to lack of replications. Energy and nitrogen partitions were expressed on the basis of metabolic body size $\left(\mathrm{W}^{0.75}\right)$. Analyses for correlation and regression were made by the method described by STEEL and TORRIE (1960) and the comparison of the treatment mean was done by Duncan's multiple range test (1955).

Table 1

Ingredient and nutrient composition of experimental diets given to the calf (Zusammensetzung und Inhaltsstoffe der vier Proteinfütterungsgruppen der Versuchskälber)

\begin{tabular}{lcccc}
\hline & \multicolumn{3}{c}{ Diet } & \\
\cline { 2 - 5 } & S B M & C S M & H S B M & G M \\
\hline Ingredient (g/kg DM unless otherwise stated) & & & 480 \\
Corn, rolled & 427 & 335 & 427 & - \\
Wheat flour & - & 60 & - & - \\
Soybean meal & 134 & - & - & - \\
Cottonseed meal & - & 160 & - & - \\
Heated soybean meal & - & - & 134 & 39 \\
Corn gluten meal & - & - & - & 400 \\
Miscellaneous & 39 & 45 & 39 & \\
Orchardgrass hay, & 400 & 400 & 400 & 853 \\
1st cut & & & & \\
Chemical composition (g/kg DM unless otherwise stated) & 849 & 856 & 942 \\
Dry matter (DM) & 842 & & & 150 \\
$\quad$ (g/kg as is) & & 933 & 937 & 356 \\
Organic matter & 156 & 153 & 149 & 205 \\
Crude protein & 366 & 398 & 371 & 18.8 \\
Neutral-detergent fiber & 203 & 227 & 215 & 18.5 \\
Acid-detergent fiber & 18.8 & 18.8 & & \\
Gross energy (MJ/kg DM) & & & \\
\hline
\end{tabular}

Results

Table 2 shows mean dry-matter intake (DMI), live weight (LW) and average daily gain 
(ADG) of calves given soybean meal (SBM), cottonseed meal (CSM), heated soybean meal (HSBM) and corn gluten meal (CGM) diets at growth (G), maintenance (M) and fasting (F) periods. Daily DMI was about $2 \mathrm{~kg}$ for all diet treatments at $\mathrm{G}$ period and about $1.3 \mathrm{~kg}$ at M period. Mean ADG was about $0.5 \mathrm{~kg}$ for all diet treatments at $\mathrm{G}$ period as expected and showed slightly negative values at M period. Mean LW of F period decreased 8 to $10 \%$ of those at M period, which resulted in 70 to $80 \mathrm{~kg}$.

Table 2

The dry-matter intake (DMI), live weight (LW) and average daily gain (ADG) of calves given soybean meal (SBM), cottonseed meal (CSM), heated soybean meal (HSBM) or corn gluten meal (CGM) diet at growth $(\mathrm{G})$ or maintenance $(\mathrm{M})$ level of feeding, and fasting $(\mathrm{F})$ (Trockensubstanzaufnahme, Lebendgewicht und tägliche Zunahme der Kälber der vier Fütterungsgruppen während der Wachstums- und Nachsorgephase)

\begin{tabular}{|c|c|c|c|c|c|c|c|c|}
\hline & & & & & LW & & & \\
\hline Diet & & & day) & & (kg) & & (kg & day) \\
\hline & & G & M & G & M & $\mathrm{F}$ & G & M \\
\hline SBM & Mean & 1. 94 & 1.26 & 80.7 & 80.4 & 71.1 & 0.56 & -0.02 \\
\hline & s. d. & 0 & 0 & 7.1 & 7.7 & 6.2 & 0.24 & 0.04 \\
\hline CSM & Mean & 1.95 & 1. 27 & 82.9 & 80.8 & 73.9 & 0.55 & -0.15 \\
\hline & s. d. & 0 & 0 & 4.8 & 4.2 & 4. 2 & 0.14 & 0.06 \\
\hline HSBM & Mean & 1.97 & 1.28 & 85.6 & 85.1 & 78.4 & 0.51 & -0.03 \\
\hline & s. d. & 0 & 0 & 5.3 & 7.0 & 5.7 & 0.16 & 0.12 \\
\hline CGM & Mean & 1. 97 & 1.29 & 89.9 & 89.6 & 81.5 & 0.53 & -0.02 \\
\hline & s. d. & 0 & 0 & 1. 0 & 1.7 & 1.9 & 0.07 & 0.07 \\
\hline
\end{tabular}

The mean digestibility at $G$ period was shown in Table 3 for dry matter (DM), organic matter (OM), neutral detergent fiber (NDF), acid detergent fiber (ADF) and cellular content (CC) for 4 diets. The digestibility of DM was about 0.7 for all diets except for CSM diet that was significantly lower than those for the others. Digestibilities of OM, NDF and ADF did not differ among diets except for CSM diet that was significantly lower than the other diets. The digestibility of CC was about 0.84 for all diets.

Table 3

The mean digestibilities with standard deviation (s.d.) for dry matter (DM), organic matter $(\mathrm{OM})$, neutral detergent fiber (NDF), acid detergent fiber (ADF) and cellular content (CC) of calves given soybean meal (SBM), cottonseed meal (CSM), heated soybean meal (HSBM) diet or corn gluten meal (CGM) diet at growth level of feeding (Verdaulichkeit und Standardabweichung für die Futterinhaltsstoffe der vier Proteingruppen während der Wachstums- und Nachsorgephase)

\begin{tabular}{lllllll}
\hline \multicolumn{2}{c}{ Diet } & D M & 0 M & NDF & ADF & C C \\
\hline SBM & Mean & $0.701^{\mathrm{a} 1)}$ & $0.713^{\mathrm{a}}$ & $0.440^{\mathrm{a}}$ & $0.425^{\mathrm{a}}$ & 0.843 \\
& s. d. & 0.026 & 0.024 & 0.064 & 0.027 & 0.016 \\
CSM & Mean & $0.634^{\mathrm{b}}$ & $0.647^{\mathrm{b}}$ & $0.334^{\mathrm{b}}$ & $0.322^{\mathrm{b}}$ & 0.826 \\
& s. d. & 0.010 & 0.012 & 0.035 & 0.030 & 0.016 \\
HSBM & Mean & $0.701^{\mathrm{a}}$ & $0.710^{\mathrm{a}}$ & $0.457^{\mathrm{a}}$ & $0.435^{\mathrm{a}}$ & 0.843 \\
& s. d. & 0.020 & 0.022 & 0.052 & 0.036 & 0.015 \\
CGM & Mean & $0.709^{\mathrm{a}}$ & $0.719^{\mathrm{a}}$ & $0.452^{\mathrm{a}}$ & $0.417^{\mathrm{a}}$ & 0.847 \\
& s. d. & 0.007 & 0.007 & 0.030 & 0.023 & 0.020 \\
\hline
\end{tabular}

${ }^{1)}$ Figures with different superscripts on the same column differ significantly $(\mathrm{P}<0.01)$. 
Table 4

Mean values and standard deviation (s.d.) for nitrogen intake, nitrogen excreted in feces and urine, and $\mathrm{N}$ retention (NR) of calves given soybean meal (SBM), cottonseed meal (CSM), heated soybean meal (HSBM) or corn gluten meal (CGM) diet at growth (G) or maintenance (M) level of feeding, and fasting (F) (Durchschnittswerte und Standardabweichung für N-Aufnahme, N-Ausscheidung in Kot und Harn und NRetention der Kälber der vier Proteingruppen in der Wachstums- und Fastenzeit)

\begin{tabular}{|c|c|c|c|c|c|c|c|c|c|c|}
\hline \multicolumn{2}{|c|}{ Diet } & \multicolumn{2}{|c|}{$\begin{array}{l}\text { Nitrogen } \\
\qquad\left(\mathrm{g} / \mathrm{W}^{0.75} \cdot \text { day }\right)\end{array}$} & \multicolumn{2}{|c|}{$\begin{array}{l}\text { Fecal N excreted } \\
\left(\mathrm{g} / \mathrm{W}^{0.75} \cdot \text { day }\right)\end{array}$} & \multicolumn{3}{|c|}{$\begin{array}{l}\text { Urinary } N \text { excretion } \\
\quad\left(\mathrm{g} / \mathrm{W}^{0.75} \cdot \text { day }\right)\end{array}$} & \multicolumn{2}{|c|}{$\begin{array}{c}\text { N R } \\
\left(\mathrm{g} / \mathrm{W}^{0.75} \cdot \text { day }\right)\end{array}$} \\
\hline & & G & M & G & M & G & M & $\mathrm{F}$ & G & M \\
\hline \multirow[t]{2}{*}{ SBM } & Mean & 1.81 & 1.17 & $0.63^{\mathrm{a} 1)}$ & $0.39^{\mathrm{a}}$ & 0.51 & $0.42^{\mathrm{a}}$ & 0.47 & $0.67^{\mathrm{a}, \mathrm{b}}$ & $0.36^{\mathrm{a}, \mathrm{b}}$ \\
\hline & s. d. & 0.12 & 0.08 & 0.03 & 0.02 & 0.17 & 0.03 & 0.13 & 0.15 & 0.08 \\
\hline \multirow[t]{2}{*}{ CSM } & Mean & 1.75 & 1. 15 & $0.71^{\mathrm{b}}$ & $0.42^{\mathrm{a}}$ & 0.47 & $0.40^{\mathrm{a}}$ & 0.46 & $0.57^{\mathrm{a}}$ & $0.33^{\mathrm{a}}$ \\
\hline & s. d. & 0.08 & 0.04 & 0.05 & 0.02 & 0.02 & 0.03 & 0.11 & 0.08 & 0.03 \\
\hline \multirow[t]{2}{*}{ HSBM } & Mean & 1.70 & 1. 10 & $0.57^{\mathrm{a}}$ & $0.31^{b}$ & 0.41 & $0.31^{b}$ & 0.48 & $0.72^{b}$ & $0.48^{b}$ \\
\hline & s. d. & 0.07 & 0.06 & 0.03 & 0.01 & 0.10 & 0.06 & 0.05 & 0.09 & 0.11 \\
\hline \multirow[t]{2}{*}{ CGM } & Mean & 1.65 & 1.06 & $0.54^{\mathrm{a}}$ & $0.33^{\mathrm{a}, \mathrm{b}}$ & 0.48 & $0.34^{\mathrm{a}, \mathrm{b}}$ & 0.45 & $0.63^{\mathrm{a}, \mathrm{b}}$ & $0.39^{\mathrm{a}, \mathrm{b}}$ \\
\hline & s. d. & 0.01 & 0.01 & 0.03 & 0.03 & 0.13 & 0.13 & 0.07 & 0.08 & 0.14 \\
\hline
\end{tabular}

${ }^{1)}$ Figures with different superscripts on the same column differ significantly $(\mathrm{P}<0.05)$.

Nitrogen (N) balance was shown in Table 4 for G, M and F periods. There were no significant differences in $\mathrm{N}$ intake among diets $(\mathrm{P}>0.05)$. $\mathrm{N}$ digestibility, however, was lower in CSM diet for G level than the other diets, and was higher in HSBM diet for M level than SBM and CGM diets. Urinary $\mathrm{N}$ excretion did not differ significantly among diets at $G$ level. HSBM, however, tended to be less than the others. No significant differences were found in the urinary $\mathrm{N}$ excretion among diet groups in fasting period, being in the range of 0.45 to $0.48 \mathrm{~g} / \mathrm{W}^{0.75}$. N retention also tended to be greater in HSBM diet both for G and M levels than other diets.

Table 5

Effective degradability (dg) and degradation kinetics of nitrogen of soybean meal (SBM), cottonseed meal (CSM), heated soybean meal (HSBM) and corn gluten meal (CGM) measured in situ technique and ruminal passage rate (k) measured with chromium mordanted NDF $^{1)}$ (Effektiver Stickstoffabbau und Energieumwandlung des Stickstoffs bei den vier Proteinquellen gemessen mit in situ Technik sowie Messung der Rumenpassagerate)

\begin{tabular}{lccccc}
\hline N source & $\mathrm{a}^{2)}$ & $\mathrm{b}$ & $\mathrm{c}$ & $\mathrm{k}$ & $\mathrm{dg}$ \\
\hline SBM & 30.2 & 56.8 & 0.054 & 0.0324 & 0.657 \\
CSM & 34.4 & 60.6 & 0.025 & 0.0511 & 0.543 \\
HSBM & 14.4 & 74.0 & 0.028 & 0.0370 & 0.463 \\
CGM & 14.0 & 34.3 & 0.146 & 0.0384 & 0.412 \\
\hline
\end{tabular}

${ }^{\mathrm{T}}$ Statistical analysis was not possible due to lack of replications.

${ }^{2)} \mathrm{a}$ : readily degradable fraction, expressed as \%, b: slowly degradable fraction, expressed as \%, c: degradation rate of slowly degradable fraction.

Table 5 shows effective degradability (dg) and degradation kinetics of $\mathrm{N}$ for SBM, CSM, HSBM and CGM. Statistical analyses, however, were not possible for the values of dg, degradation kinetics of $\mathrm{N}$ and the passage rate due to lack of replications. The dg for SBM or CSM was higher than that for HSBM or CGM. Results of $\mathrm{N}$ degradation kinetics showed that SBM and CSM were greater in readily degradable fraction than HSBM and CGM, while slowly degradable fraction was higher in HSBM 
than the other $\mathrm{N}$ sources. CGM contained the least level of slowly degradable fraction among $\mathrm{N}$ sources, but it exhibited the highest degradation rate of slowly degradable fraction among $\mathrm{N}$ sources. CSM contained similar level of slowly degradable fraction to SBM, but showed a slower rate of degradation of the fraction compared to that of SBM. The passage rate of ruminal digesta was fairly similar among SBM, HSBM and CGM, but was greater in CSM than other sources.

Table 6

The intake of metabolizable energy (IME), heat production, digestibility of energy and metabolizability of calves given soybean meal (SBM), cottonseed meal (CSM), heated soybean meal (HSBM) or corn gluten meal (CGM) diet at growth (G) and maintenance (M) level of feeding, and fasting (F) (Die Zufuhr der metabolischen Energie, Wärmeproduktion und Energieverdaulichkeit bei den vier Proteinquellen während der Wachstums- und Fastenzeit)

\begin{tabular}{|c|c|c|c|c|c|c|c|c|c|c|}
\hline \multicolumn{2}{|c|}{ Diet } & \multicolumn{2}{|c|}{$\begin{array}{c}\operatorname{I~M~E~} \\
\left(\mathrm{kJ} / \mathrm{W}^{0.75} \cdot \text { day }\right)\end{array}$} & \multicolumn{2}{|c|}{ Digestibility } & \multicolumn{3}{|c|}{$\begin{array}{l}\text { Heat Production } \\
\left(\mathrm{kJ} / \mathrm{W}^{0.75} \cdot \text { day }\right)\end{array}$} & \multicolumn{2}{|c|}{$\begin{array}{l}\text { Metabolizability } \\
\text { (q) }\end{array}$} \\
\hline & & G & M & G & M & G & M & $\mathrm{F}$ & G & M \\
\hline \multirow[t]{2}{*}{ SBM } & Mean & $839^{\mathrm{a1})}$ & 510 & $0.687^{\mathrm{a}}$ & $0.677^{\mathrm{a}}$ & $672^{a}$ & $529^{a, b}$ & $412^{\mathrm{a}}$ & $0.616^{\mathrm{a}}$ & $0.574^{\mathrm{a}}$ \\
\hline & s. d. & 45 & 40 & 0.024 & 0.024 & 30 & 34 & 10 & 0.021 & 0.007 \\
\hline \multirow[t]{2}{*}{ CSM } & Mean & $743^{b}$ & 506 & $0.629^{b}$ & $0.667^{\mathrm{a}}$ & $590^{b}$ & $510^{\mathrm{a}}$ & $397^{\mathrm{a}}$ & $0.552^{b}$ & $0.570^{\mathrm{a}}$ \\
\hline & s. d. & 40 & 24 & 0.024 & 0.022 & 63 & 16 & 11 & 0.012 & 0.018 \\
\hline \multirow[t]{2}{*}{ HSBM } & Mean & $782^{\mathrm{b}}$ & 523 & $0.682^{\mathrm{a}}$ & $0.717^{\mathrm{b}}$ & $697^{\mathrm{a}}$ & $556^{\mathrm{b}}$ & $340^{\mathrm{b}}$ & $0.596^{\mathrm{a}}$ & $0.616^{\mathrm{b}}$ \\
\hline & s. d. & 15 & 47 & 0.024 & 0.011 & 24 & 33 & 33 & 0.024 & 0.021 \\
\hline \multirow[t]{2}{*}{ CGM } & Mean & $780^{b}$ & 489 & $0.692^{\mathrm{a}}$ & $0.689^{\mathrm{a}, \mathrm{b}}$ & $683^{\mathrm{a}}$ & $553^{\mathrm{b}}$ & $354^{\mathrm{b}}$ & $0.608^{\mathrm{a}}$ & $0.589^{\mathrm{a}, \mathrm{b}}$ \\
\hline & s. d. & 5 & 52 & 0.061 & 0.063 & 5 & 27 & 20 & 0.007 & 0.063 \\
\hline
\end{tabular}

${ }^{1)}$ Figures with different superscripts on the same column differ significantly $(\mathrm{P}<0.05)$.

Results of energy balance were summarized in Table 6. The intake of ME for G level feeding was significantly greater in SBM diet than the other diets, but showed no significant difference in $\mathrm{M}$ level feeding among diets as expected. The energy digestibility was significantly lower in CSM diet than other diets for G level, but tended to be higher in HSBM diet than other diets for M level. The energy digestibility and metabolizability for each diet showed inconsistent results and were not significantly different between $M$ and $G$ levels. Heat production was significantly lower in CSM diet than other diets for G level. Although there was no statistically significant difference among the other diets, SBM tended to be lower than HSBM and CGM. For M level feeding, SBM and CSM diets tended to be lower than HSBM and CGM diets, although there was no statistically significant difference among SBM, HSBM and CGM diets. At fasting, animals in HSBM and CGM diet groups showed a significantly lower heat production than those in other tow groups. CSM diet showed the least values among diets for $\mathrm{G}$ level feeding and tended to be the least for the $\mathrm{M}$ level.

With the results of energy balance, regression of energy retention on ME intake has been analyzed for each diet at $\mathrm{G}$ and $\mathrm{M}$ level of feeding. For $\mathrm{M}$ level of feeding, negative values were obtained in the energy retention and average daily gain for each diet group. Regression equations presented in Table 7, therefore, were expressed as those above maintenance for $\mathrm{G}$ level and those below maintenance for $\mathrm{M}$ level feeding. ME for maintenance (MEm) calculated were also presented in Table 7. 
Regression analysis for $G$ level feeding revealed that each diet showed a somewhat varied regression coefficient for a single equation ranging from 0.461 for HSBM to 0.644 for CSM. There was, however, no statistically significant difference among those coefficients. Thus, results were combined to calculate one pooled equation. The regression coefficient showed that the efficiency of the utilization of ME was $0.563 \pm 0.047$ for $G$ level feeding adopted in the present study. The MEm was calculated to be $552 \mathrm{~kJ} / \mathrm{W}^{0.75}$ for calves at the age of 3 to 4 months. For M level feeding, SBM and CSM diets showed higher regression coefficients than HSBM and CGM diets. Thus, two pooled equations were separately calculated by combining each of two different groups. The regression coefficients of the pooled equation showed that the efficiency of ME utilization was $0.773 \pm 0.019$ for SBM and CSM diets, and $0.600 \pm 0.030$ for HSBM and CGM diets of $M$ level feeding adopted in the present study. The MEm was calculated to be $521 \mathrm{~kJ} / \mathrm{W}^{0.75}$ for feeding of SBM and CGM diets and $583 \mathrm{~kJ} / \mathrm{W}^{0.75}$ for feeding of HSBM and CGM diets, respectively. The MEm calculated by the pooled equation for feeding of HSBM and CGM diets showed a little higher value than that obtained for feeding of SBM and CGM diets. The MEm calculated from the pooled equation above maintenance was a similar to those for the below $\mathrm{M}$.

\section{Table 7}

Regression analyses of energy retention (ER, $\mathrm{kJ} / \mathrm{W}^{0.75}$-day) on intakes of metabolizable energy (IME, $\mathrm{kJ} / \mathrm{W}^{0.75}$ - day) for calves given soybean meal (SBM), cottonseed meal (CSM), heated soybean meal (HSBM) or corn gluten meal (CGM) diet and metabolizable energy for maintenance (MEm, kJ/W $\mathrm{W}^{0.75}$. day) (Regressionsanalyse der N-Retention und Zufuhr der metabolischen Energie bei Kälbern bei den vier Proteinquellen und der metabolischen Energie im Nachsorgestand)

\begin{tabular}{|c|c|c|c|c|}
\hline Diet & Equation & $r$ & s. e. & $\mathrm{MEm}^{1}$ \\
\hline$\overline{\text { SBM above maintenance }}$ & $\overline{E R}=0.570( \pm 0.051) \mathrm{IME}-311$ & $0.969^{\text {** }}$ & 8.8 & 546 \\
\hline CSM above maintenance & $\mathrm{ER}=0.644( \pm 0.108) \mathrm{IME}-324$ & $0.904^{* *}$ & 13.3 & 503 \\
\hline HSBM above maintenance & $\mathrm{ER}=0.461( \pm 0.067) \mathrm{IME}-274$ & $0.942^{* *}$ & 8.9 & 594 \\
\hline CGM above maintenance & $\mathrm{ER}=0.592( \pm 0.081) \mathrm{IME}-324$ & $0.948^{* *}$ & 12.1 & 547 \\
\hline Pooled above maintenance & $\mathrm{ER}=0.563( \pm 0.047) \mathrm{IME}-311$ & $0.896^{* *}$ & 7.0 & 552 \\
\hline SBM below maintenance & $\mathrm{ER}=0.771( \pm 0.033) \mathrm{IME}-414$ & $0.993^{* *}$ & 8.7 & 537 \\
\hline CSM below maintenance & $\mathrm{ER}=0.779( \pm 0.020) \mathrm{IME}-397$ & $0.997^{* *}$ & 5.2 & 510 \\
\hline Pooled below maintenance & $\mathrm{ER}=0.773( \pm 0.019) \mathrm{IME}-403$ & $0.994^{* *}$ & 7.0 & 521 \\
\hline HSBM below maintenance & $\mathrm{ER}=0.592( \pm 0.040) \mathrm{IME}-343$ & $0.986^{* *}$ & 10.8 & 579 \\
\hline CGM below maintenance & $\mathrm{ER}=0.608( \pm 0.051) \mathrm{IME}-358$ & $0.979^{* *}$ & 12.7 & 589 \\
\hline Pooled below maintenance & $\mathrm{ER}=0.600( \pm 0.030) \mathrm{IME}-350$ & $0.982^{* *}$ & 7.8 & 583 \\
\hline
\end{tabular}

\section{Discussion}

The supplies of ME were satisfactory for the growth and maintenance levels because ADG was almost the same as expected for growth level feeding and was nearly zero with a slightly negative values, irrespective of protein sources in a diet. Fasting for 3 days produced 8 to $10 \%$ of live weight reduction irrespective of protein sources, which is fairly comparable to the standard of weight loss described in the equation estimating fasting heat production of cattle by ARC (1988). Thus, the protein sources used have no influence on the maintenance and the growth level adopted in the present study. 
Calves digested nutrients similarly in different diets at the growth level feeding except for CSM diet. Calves of 8 to 20 weeks of age have shown overall digestion unaffected for diets consisting of $60 \%$ concentrate and $40 \%$ chopped hay with varying protein degradability (CUMMINS et al., 1982). Inclusion of CSM in the diet, however, appeared to reduce the digestibility of the diet (CUMMINS et al., 1982). Results of the present study showed a low degradation rate of slowly degradable fraction of $\mathrm{N}$ for CSM (Table 5), which may have caused a lower digestibility for fibrous fractions such as NDF and ADF. In addition, the rumen passage showed a greater rate for CSM diet than the other diets (Table 5). The lower digestibility of DM or OM for CSM diet in the present study, therefore, may have been attributed to a low degradation rate of slowly degradable fraction of $\mathrm{N}$ intrinsic to CSM as a protein source together with a greater passage rate of CSM diet. Digestibilities of nutrients in CSM diet, however, were fairly comparable to those obtained by sheep and goats when they were given the diet of the same ratio of formula feed to Italian ryegrass hay as that of the present study (SEKINE et al., 1992). The CSM diet in the present study also satisfactorily supported the expected growth of calves. Thus, CSM may be satisfactorily used as a protein source for growing calves.

$\mathrm{N}$ intake was similar among diets with some divergence at $\mathrm{G}$ and $\mathrm{M}$ level feeding as expected. Although $\mathrm{N}$ excreted in feces was greater in CSM diet at $\mathrm{G}$ level feeding, the urinary $\mathrm{N}$ excretion showed no significant difference among diets with a tendency to be less in HSBM diet. This result may have resulted in a higher $\mathrm{N}$ retention for HSBM diet at $G$ level feeding, which is not reflected to the level of average daily gain at $G$ level feeding, though. Average daily gain showed a slightly negative value for all diets at $\mathrm{M}$ level feeding, nevertheless the $\mathrm{N}$ retention was positive for all diets. ROY (1970) pointed out that the effect of gut fill should be considered when comparing the performance of calves. Ewes of $51 \mathrm{~kg}$ of live weight carried 8 to $9 \mathrm{~kg}$ of fresh digesta in the whole digestive tract when consuming about $0.4 \mathrm{~kg}$ of hay (SEKINE et al., 1991), that is, 16 to $18 \%$ of live weight is estimated to represent gut fill for ruminants. Thus, live weight change apparently observed may have differed from a true change in daily gain. Also, reduced feed intake may have caused differences in fresh contents in the digestive tract among different diets as speculated from changes in live weight from $\mathrm{G}$ to $\mathrm{M}$ level feeding for each diet. This may be supported by results of urinary $\mathrm{N}$ excretion at fasting. Since no significant differences were observed in the urinary $\mathrm{N}$ excretion at fasting among diet groups, the least requirement for $\mathrm{N}$ may be in a range of 0.45 to $0.48 \mathrm{~g} / \mathrm{W}^{0.75}$ for calves at 3 to 4 months of age irrespective of protein sources in a diet.

The values for $\mathrm{dg}$ of $\mathrm{N}$ determined in the present study were comparable to the mean for SBM, CSM, HSBM and CGM presented in the Japanese Feeding Standard for Dairy Cattle (AFFRC, 1999), and were all within the ranges presented in the table. CGM showed the least dg value among protein sources as expected, but it was fairly comparable to that of HSBM. This may have been attributed much faster degradation rate of slowly degradable fraction of CGM, even though the level of the fraction was the least among protein sources.

The energy digestibility and metabolizability for each diet were inconsistent between $\mathrm{M}$ and $\mathrm{G}$ levels. The measurement for $\mathrm{M}$ and $\mathrm{G}$ levels was carried out in different ages. This difference in the age in growing period may have caused inconsistency for results of the energy digestibility and metabolizability for M and G levels. The DMI 
for $\mathrm{G}$ levels was about 1.5 times of those for $\mathrm{M}$ levels. This less distinctive difference for DMI may also have affected the inconsistency for results of the digestibility and metabolizability for $\mathrm{M}$ and $\mathrm{G}$ levels. Results of digestibility of energy reflected to those for metabolizability, that is, CSM with a low OM digestibility showed a lower metabolizability of energy at $\mathrm{G}$ level feeding. The digestibility of energy for CSM also lower than other diets at $\mathrm{G}$ level feeding. The same trend for metabolizabililty has been observed at M level feeding, that is, HSBM and CGM with a higher digestibility of energy tended to be a higher metabolizability than SBM and CSM. HSBM and CGM diets with a lower dg value of protein tended to have a higher heat production at $\mathrm{G}$ and $\mathrm{M}$ levels of feeding, which resulted in a tendency of lower energy retention. This may have caused a tendency of lower daily gain for HSBM and CGM groups compared with SBM and CSM groups, although there was no statistical significance. However, fasting heat production was significantly lower in HSBM and CGM groups than SBM and CSM groups. Yet, the former groups tended to show a higher heat production at both feeding periods than the latter groups. This phenomenon may have resulted from the difference in metabolic utilization of nutrients delivered from diets of different rumen degradability (HOCQUETTE et al., 2001). The nutrients in different diets may have been supplied in a different proportion of slow and fast type fuels as a result of different protein degradability, which may affect the regulation of energy metabolism (HOCQUETTE et al., 2001). However, results of the present study may not present clear evidence because kinetics of nutrient absorption are less marked in ruminants with buffering effect of the rumen fermentation than in monogastric animals (HOCQUETTE et al., 2001).

Regression analyses of energy retention on intakes of $\mathrm{ME}$ showed no significant differences in the efficiency of ME utilization for growth $\left(k_{g}\right)$ among four diets with some variations among them, and $k_{g}$ was calculated to be 0.563 for the pooled equation. This value is a little higher than the value calculated from the equation presented in the British standard $\left(k_{f}=0.469\right.$; ARC, 1988). HOCQUETTE et al. (2001) have referred to a more than 0.5 of $k_{g}$ for weaned growing ruminants given maizebased diets. INRA (1978) also described the efficiency of ME utilization for fattening and growth to be between 0.30 and 0.56. ORTIGUES et al. (1990) have reported that the values of $k_{f}$ were 0.377 and 0.525 for heifers offered straw-based diets supplemented with high and low levels of fishmeal. Thus, these evidences support the result obtained in the present study. Therefore, difference in dg of protein sources in a diet may have little influence, if any, on the $k_{g}$ for growing calves with a relatively low daily gain such as $0.5 \mathrm{~kg} /$ day in the present study. On the other hand, the efficiency of ME utilization for maintenance $\left(k_{m}\right)$ differed between diets of protein sources with low dg values such as HSBM or CGM and high dg values such as SBM or CSM. The pooled equation of the latter group showed a comparable dg value to that calculated from the equation presented in the British standard $\left(k_{m}=0.71\right.$; ARC, 1988) or in the French standard $\left(k_{m}=0.72\right.$; INRA, 1989). The $k_{m}$ obtained from the pooled equation of the former group was lower than the calculated value from the equation presented in the British standard $\left(k_{m}=0.71\right.$; ARC, 1988) or in the French standard $\left(k_{m}=0.73\right.$; INRA, 1989). Thus, a diet with protein sources of low dg values may reduce the efficiency of ME utilization by calves at $\mathrm{M}$ level feeding. This phenomenon may have resulted from a lowered efficiency of microbial proliferation in the rumen because of the reduced level of degradable $\mathrm{N}$ in the rumen. 
The MEm calculated by the pooled equation above maintenance $(\mathrm{MEm}=552$ $\mathrm{kJ} / \mathrm{W}^{0.75}$ ) was resulted in a range of those obtained from the pooled equations below maintenance. The value was well agreed with that calculated from the equations presented in the British standard using values obtained in the present study for calculation $\left(\mathrm{MEm}=551 \mathrm{~kJ} / \mathrm{W}^{0.75}\right.$; ARC, 1988). The MEm calculated by the pooled equation below maintenance for SBM and CSM $\left(\mathrm{MEm}=521 \mathrm{~kJ} / \mathrm{W}^{0.75}\right)$ was also well agreed with that calculated from the equations presented in the British standard (MEm $=524 \mathrm{~kJ} / \mathrm{W}^{0.75}$; ARC, 1988). The MEm calculated by the pooled equation below maintenance for HSBM and CGM $\left(\mathrm{MEm}=583 \mathrm{~kJ} / \mathrm{W}^{0.75}\right)$, however, was a little higher than that calculated from the equations presented in the British standard (MEm $=511$ $\mathrm{kJ} / \mathrm{W}^{0.75}$; ARC, 1988). This may have resulted from a lower efficiency of ME utilization for maintenance $\left(k_{m}=0.60\right)$ at M level feeding of HSBM and CGM. Thus, it is speculated that a diet with protein sources of low dg results in a low efficiency of ME utilization at maintenance level caused by a lowered efficiency of rumen fermentation because of a low supply of ruminally degradable $\mathrm{N}$.

In conclusion, there was no significant influence of the difference in dg of protein sources in a diet on efficiency of ME utilization at growth level feeding with expecting daily gain of $0.5 \mathrm{~kg}$. The efficiency of ME utilization for maintenance, however, was affected by the difference in dg of protein sources in a diet. Thus, it is speculated that calves may have an advantage on the utilization of ME for maintenance by feeding of a diet with protein sources of a higher rumen degradability of $\mathrm{N}$ for microbial protein synthesis in the rumen because animals require less $\mathrm{N}$ at maintenance.

\section{References}

AGRICULTURE, FORESTORY and FISHERIES RESEARCH COUNCIL SECRETARIAT: Japanese Feeding Standard for Dairy Cattle (1999). MAFF. Tokyo

AGRICULTURAL RESEARCH COUNCIL:

The Nutrient Requirements of Ruminant Livestock. (1980) Commonwealth Agricultural Bureaux, Slough

AGRICULTURAL RESEARCH COUNCIL:

The Nutrient Requirements of Ruminant Livestock. (1988) Commonwealth Agricultural Bureaux, Slough

ASSOCIATION OF OFFICIAL ANALYTICAL CHEMISTS:

Official Methods of Analysis (1970). $11^{\text {th }}$ ed., pp.122-131. AOAC, Washington DC.

CUMMINS, K. A.; NOCEK, J. E.; POLAN, C. E.:

Growth and nitrogen balance of calves fed rations of varying nitrogen degradability and physical form. J. Dairy Sci., 65 (1982), 773-783

DUNCAN, D. B.:

Multiple range and multiple $F$ tests. Biometrics, 11 (1955), 1-42

GILL, M.; BEEVER, D. E.; BUTTERY, P. J.; ENGLAND, P.; GIBBS, M. J.; BAKER, R. D.:

The effect of oestradiol-17 $\beta$ implantation on the response in voluntary intake, live-weight gain and body composition, to fish meal supplementation of silage offered to growing calves. J. Agric. Sci., Camb., 108 (1987), 9-16

GOERING, H. K.; VANSOEST, P. J.:

Forage Fiber Analyses. Agriculture Handbook No.379, (1970) Agricultural Research Service, Washington, D. C.

HOCQUETTE, J. F.; ORTIGUES-MARTY, I.; VERMOREL, M.:

Manipulation of tissue energy metabolism in meat-producing ruminants. - Review - Asian-Aust. J. Anim. Sci., 14 (2001), 720-732

INSTITUT NATIONAL de la RECHERCHE AGRONOMIQUE: Alimentation des Ruminants, (1978) INRA, Theix

INSTITUT NATIONAL de la RECHERCHE AGRONOMIQUE: Ruminant Nutrition, Recommended allowances and feed tables. (1989) R. JARRIGE ed., JOHN LIBBEY Eurotext, Paris 
KEYSERLINGK, von G. E. M.; MATHISON, G. W.:

The effect of ruminal escape protein and ambient temperature on the efficiency of utilization of metabolizable energy by lambs. J. Anim. Sci., 71 (1993), 2206-2217

ORSKOV, E. R.; McDONALD, I.:

The estimation of protein degradability in the rumen from incubation measurements weighted according to rate of passage. J. agric. Sci., 92 (1979), 499-503

ORTIGUES, I.; SMITH, T.; GILL, M.; CAMMEL, S. B.; YARROW, N. W.:

The effect of fish meal supplementation of a straw-based diet on growth and calorimetric efficiency of growth in heifers. Br. J. Nutr., 64 (1990), 639-651

ROY, J. H. B.:

The Calf, Volume 2, Nutrition and Health, (1970) $3^{\text {rd }}$ ed. Iliffe Books Ltd. London

RUSSEL, A. J. F.; WRIGHT, I. A.:

Factors affecting maintenance requirements of beef cows. Anim. Prod., 37 (1983), 329-334

SEKINE, J.; ASAHIDA, Y. :

Energy metabolism of calf. JARQ, 24 (1990), 141-148

SEKINE, J.; KAMEL, H. E. M.; FADEL EL-SEED, A. N. M. A.; HISHINUMA, M.:

Estimation of rumen gas volume by dilution technique in sheep given two silages at different levels of Feeding. Asian-Aust. J. Anim. Sci., 16 (2003), 380-383

SEKINE, J.; OURA, R.; ASAHIDA, Y.:

Effects of ratio of concentrate to roughage and kinds of hay in a ration on estimating the rumen degradability of protein of formulated concentrate. Asian-Aust. J. Anim. Sci., 5 (1992), 19-24

SEKINE, J.; OURA, R.; MIYAZAKI, H.; OKAMOTO, M.; ASAHIDA, Y.:

Effect of time after feeding on distribution of digesta in the gastro-intestinal tracts of sheep. Asian-Aust. J. Anim. Sci., 4 (1991), 99-102

STEEL, R. G. D.; TORRIE, J. H.:

Principles and Procedures of Statistics. (1960) McGraw-Hill Book Co. Inc. New York

VEIRA, D. M. BUTLER, G.; IVAN, M.; PROULX, J. G.:

Utilization of grass silage by cattle: Effect of barley and fishmeal supplements. Can. J. Anim. Sci., 65 (1985), 897-903

VEIRA, D. M.; PROULX, J. G.; BUTLER, G.; FORTIN, A.:

Utilization of grass silage by cattle: Further observations on the effect of fish meal. Can. J. Anim. Sci., 68 (1988), 1225-1235

VEIRA, D. M.; PROULX, J. G.; SEOANE, J. R.:

Performance of beef steers fed grass silage with or without supplements of soybean meal, fish meal and barley. Can. J. Anim. Sci., 70 (1990), 313-317

Received: 2003-05-05

Accepted: 2004-06-22

Author's addresses

Dr. JUNJIRO SEKINE, PhD, Dr. MITSUGU HISHINUMA*, PhD, Mr. ABDEL NASIR M. A.

FADEL EL-SEED, MS.

Department of Veterinary Science, Faculty of Agriculture, Tottori University, Tottori, Japan

Dr. HOSSAM E. M. KAMEL, PhD

Department of Animal Production, Faculty of Agriculture,

Alexandria University, El-Shatby, Alexandria, Egypt

Dr. SHIGERU MORITA, PhD

Department of Dairy Science, Rakuno Gakuen University, Ebetsu, Japan

Mr. MASA-AKI HANADA, MS.

Department of Animal Science, Obihiro University of Agriculture and

Veterinary Medicine, Obihiro, Japan

Dr. SEIJI KONDO, PhD

Department of Animal Science, Faculty of Agriculture,

Hokkaido University, Sapporo, Japan

*Corresponding author

Dr. MITSUGU HISHINUMA

Department of Veterinary Medicine, Faculty of Agriculture, Tottori University,

Tottori 680-8553, Japan

E-mail: mhishi@muses. tottori-u. ac.jp 